\title{
Physiological and Molecular Characterization of Crop Resistance to Abiotic Stresses
}

\author{
Monica Boscaiu ${ }^{1, *}$ and Ana Fita 2 (D) \\ 1 Mediterranean Agroforestry Institute (IAM), Universitat Politècnica de València, Camino de Vera 14, \\ 46022 Valencia, Spain \\ 2 Institute for the Conservation and Improvement of Valencian Agrodiversity (COMAV), Universitat \\ Politècnica de València, Camino de Vera 14, 46022 Valencia, Spain; anfifer@btc.upv.es \\ * Correspondence: mobosnea@eaf.upv.es; Tel.: +34-963-879-253
}

Received: 3 August 2020; Accepted: 26 August 2020; Published: 2 September 2020

check for updates

\begin{abstract}
Abiotic stress represents a main constraint for agriculture, affecting plant growth and productivity. Drought and soil salinity, especially, are major causes of reduction of crop yields and food production worldwide. It is not unexpected, therefore, that the study of plant responses to abiotic stress and stress tolerance mechanisms is one of the most active research fields in plant biology. This Special Issue compiles 22 research papers and 4 reviews covering different aspects of these responses and mechanisms, addressing environmental stress factors such as drought, salinity, flooding, heat and cold stress, deficiency or toxicity of compounds in the soil (e.g., macro and micronutrients), and combination of different stresses. The approaches used are also diverse, including, among others, the analysis of agronomic traits based on morphological characteristics, physiological and biochemical studies, and transcriptomics or transgenics. Despite its complexity, we believe that this Special Issue provides a useful overview of the topic, including basic information on the mechanisms of abiotic stress tolerance as well as practical aspects such as the alleviation of the deleterious effects of stress by different means, or the use of local landraces as a source of genetic material adapted to combined stresses. This knowledge should help to develop the agriculture of the (near) future, sustainable and better adapted to the conditions ahead, in a scenario of global warming and environmental pollution.
\end{abstract}

Keywords: salinity; drought; heat stress; flooding; nutrient stress; ROS; cold stress

\section{Introduction}

Abiotic stress represents the main constraint for agriculture, affecting plant growth and productivity worldwide. Yield losses in agriculture will be potentiated in the future by global warming, increasing contamination, and reduced availability of fertile land [1]. The challenge of the present and future agriculture is to increase the food supply for a continuously growing human population under environmental conditions that are deteriorating in many areas of the world. Minimizing the effects of diverse types of abiotic stresses represents a matter of general concern [2].

The study of abiotic stress tolerance mechanisms is one of the most active lines of research in plant biology, given its undoubted academic interest and practical implications in agriculture. The different types of abiotic stresses imposed by the environment usually are interconnected and often have an osmotic component, affecting plant cell homeostasis [3].

To counteract abiotic stress, plants activate a series of stress responses, which are shared by both sensitive and tolerant plants as they use the same basic effectors [4]. The knowledge of the limits of tolerance to abiotic stress of different crops, and the understanding of their mechanisms of response to increasing environmental constraints are gaining importance in agronomic research [5]. Research on 
crop abiotic stress responses is diverse, as plants undergo specific changes in their gene expression, metabolism, and physiology in response to different environmental stress conditions [6].

In this Special Issue, 22 research papers and 4 reviews are presented covering different aspects of the responses of plants to abiotic stresses and their mechanisms of tolerance. However, what is considered abiotic stress? We can define it as any physical or chemical constraint to the potential development and growth of a plant not involving interactions with other living organisms. Abiotic stress in plants is a vast subject, which can be addressed from different points of view and includes many different components, mainly environmental factors, for instance: soil, water, climate, irradiation — even the moon influence! Plants have evolved a series of physiological and molecular mechanisms of response that may (or may not) allow them to adapt to and survive this broad range of stressful conditions. Understanding those mechanisms will help us to improve our interventions towards a more sustainable and efficient agriculture.

\section{Drought and Salinity}

Drought and salinity are major abiotic stresses that affect agricultural yields worldwide. The more frequent, longer, and more intense dry periods in many regions of the world, due to global warming, are associated with increasing salinization of land cultivated under irrigation. About $20 \%$ of irrigated land in the world, producing one-third of the global food, is affected by secondary salinization of the soil [7]. Drought and salinity have a common osmotic component and early responses to these two types of stress are practically identical [8]. Besides, salt stress causes ionic stress and $\mathrm{Na}^{+}$toxicity [3]. Like other types of stress, drought and salinity or their combination may trigger growth inhibition, including, for example, disturbances in mineral nutrition, alteration of membrane permeability and cellular osmotic balance, generation of oxidative stress by increasing reactive oxygen species (ROS) levels, or inhibition of different enzyme activities [9-11].

In the Special Issue is included a review on physiological changes under drought conditions that influence yields in several vegetable crops summarizing changes in the stomatal conductance and chlorophyll content of leaves for individual plants, but also the utility of water stress indices and spectral vegetation indices for predicting yields [12]. An overview by Ketehouli et al. [13] on the effects of salinity on plants and their tolerance mechanisms with particular emphasis on $\mathrm{K}^{+}$and $\mathrm{Na}^{+}$ homeostasis and transport and their regulation is also here included.

Plants defense against abiotic stress starts within their roots [3], and a well-developed root system is essential to provide water uptake [12]. The ability of plants to change their root anatomy was found to improve water uptake and transport in peanut and, therefore, may be considered as a relevant drought tolerance mechanism in this species [14].

This Special Issue includes several papers on morphological, physiological, and biochemical responses to these two types of stress or their combination, and their use in screening for stress-tolerant cultivars. Increased activities of ROS-scavenging enzymes and a more balanced $\mathrm{Na}^{+}: \mathrm{K}^{+}$ratio was reported as the main mechanism of tolerance in wheat and barley [15]. Accumulation of proline and monovalent cations was related to salt tolerance mechanism in cultivated eggplant and its wild relative Solanum insanum [16]. Of special interest is the screening of neglected varieties and local landraces, as they can be a valuable source of allelic richness. Landraces evolved due to selection of traits specifically adapted to local conditions, often suboptimal or even highly stressful [17]. Therefore, such genotypes may enhance agronomic production under the foreseeable restrictive conditions imposed by climate change [2]. Proline was the marker used for screening of beans tolerant to water and salt stress [18], or antioxidant for salt-tolerant tomatoes with high nutraceutical value [19]. Proline and chlorophyll contents, in combination with several morphological and physiological traits, are optimal markers for screening drought tolerance in provitamin A maize, used in sub-Saharan Africa to combat vitamin A deficiency [20].

The irruption of transcriptomics, metabolomics, high-throughput DNA sequencing and high-density microarrays in the analysis of plants' responses to stress have brought new insights and 
allowed a better understanding on plants reactions to stressful conditions [21]. The stress-responding genes and their regulation pattern under drought were analyzed in common buckwheat cotyledons and roots [22] and female panicles in maize [23], and under salinity in roots and leaves of pomegranate [24].

Others papers published here deal with mitigation of the effects of drought in different crops, such as the synergistic effect of silicon and inoculation with an arbuscular mycorrhizal fungus on strawberries [25], transfer of a LEA gene of a Vietnamese maize landrace to transgenic maize and tobacco [26], and that of salinity by salicylic acid, yeast extract, and proline in sweet pepper [27].

\section{Other Significant But Less Studied Stresses}

Global warming alters the rainfall regime in many areas of the world [28], leading to increased floods and poorly drained, waterlogged soils; these conditions have a negative effect on crops by reducing oxygen availability for roots and soil microorganisms [29]. Escape and resilience strategies under flooding stress are presented in an extensive review, concluding that plants maintain their internal homeostasis by balancing hormonal cross-talk under excess water stress [30]. Besides, some treatments can help plants to cope with the stressful effects of waterlogging, for example, seed priming by sodium azide $\left(\mathrm{NaN}_{3}\right)$ was found to enhance the performance of okra plants under waterlogged conditions [31].

Extreme temperatures pose another challenge for crops. Irregular weather patterns have increased their occurrence in the present climatic conditions; for example, more frequent heat waves are now reported worldwide [28]. One paper deals with the effect of heat stress in alfalfa and extensively discusses the effects of heat on plants [31]). In addition, cold is also a common stress which triggers sophisticated events that alter the biochemical composition of cells in order to protect them from damage [32,33]. Again, some treatments can reduce the negative effects of low temperatures. This is the case of studies on the physiological performance of plants, in which cold stress was alleviated by chitosan via enhancing the photosynthesis and carbon process in tea plant [34], or by 5-Aminolevulinic in cucumber [35].

\section{Combination of Different Stresses}

Usually, abiotic stresses come together. The association of drought and salinity is well known, but also that of drought with high temperatures. When different stresses combine, plants need to adjust their physiology to those specific conditions. Landraces, through their long process of farmers' selection in a pre-intensive agriculture period, offer a great opportunity to find appropriate combinations of genes and phenotypes tolerant to complex situations. The most stressful period in the Mediterranean region is summer, when drought is associated with increased temperatures, including heat waves, which are increasingly more frequent in recent years [36]. A comparative study on the responses of local landraces and a commercial cultivar of Phaseolus lunatus L. to different temperature and water stress regimes is presented here. The results indicated a better response and a marked competitiveness of one local cultivar [37]. Effects on agronomic traits of the same stresses and their combination was analyzed in African landraces of maize compared with drought and/or heat-tolerant lines [38], and some local landraces proved to be good candidates for improving stress tolerance in this crop.

\section{Soil Constrains}

Besides soil salinity, discussed above, there are several other soil constraints with an important impact on agriculture [39]. Of special interest are those related to nutrient conditions in the soil, such as soil P immobilization. Phosphorus is an essential element for plants, but is lacking in $40 \%$ of arable land. This nutrient is normally applied as P-enriched fertilizers, which contribute to increased eutrophication of water bodies [40]. Therefore, screening for cultivars with a good performance under low P-input conditions is of interest, as shown by an analysis of morphological traits in relation to $\mathrm{P}$ accumulation in pepper cultivars [41]. Zinc is a microelement necessary for plants, animals, and humans; when it is not present in the soil in sufficient amounts, it is necessary either to use varieties with a better uptake of this micronutrient, or its external application in the form of fertilizers and foliar sprays [42]. 
However, when in excess it has a toxic effect for plants [43]. Morphological and physiological traits, in combination with the transcriptional regulation of aquaporin isoforms expression, were analyzed in pak choi subjected to two Zn concentrations [44].

Nitrogen is necessary for plant development; it is required in large quantities and, therefore, supplied to crops in fertilizers [45]. Nevertheless, an excessive $\mathrm{N}$ application was reported to decrease ROS scavenging ability, and to cause significant metabolic changes in wheat [46]. In the same species, the use of new ecofriendly polymeric-coated urea fertilizers insured a balanced proportion of $\mathrm{N}$ with beneficial effects [47].

Another paper deals with abiotic stress in crops imposed by treatments with herbicides and explores the possibility to control weeds with three natural compounds, analyzing the phytotoxic effects that they produce in weeds. The tree products demonstrated great possibilities as sustainable tools for integrated weed management [48].

Finally, this special issue also includes a review on some questions and beliefs that still impregnate a large part of agricultural traditions and agronomic practices, according to which the different lunar phases are beneficial or stressful to plant growth and development [49]. To address the possible link between the phases of the moon and agriculture from a scientific perspective, the authors analyzed physics and biology research papers and handbooks, focusing on those abiotic factors that have a proved influence on plant growth, searching specifically for any that could explain the influence of the moon on plant growth. They did not find any reliable, science-based evidence for such a relationship.

\section{Conclusions}

The papers included in this special issue cover a broad range of topics related to the effects on crop plants of different types of abiotic stress, at the morphological, physiological, biochemical, and molecular levels, and the mechanisms of defense of the plants against these stresses. The methods employed were also diverse, from the analysis of agronomic traits based on morphological characteristics to omics approaches and the use of transgenics. Special attention was given to the screening for stress tolerance in local landraces, stress alleviation using different strategies, and the proposal of practical solutions for the agriculture of the (near) future, threatened by global warming and environmental pollution.

Author Contributions: M.B. and A.F. equally contributed to organizing the special issue, editorial work, and writing this editorial. All authors have read and agreed to the published version of the manuscript.

Funding: No external funding was obtained.

Acknowledgments: Many thanks to the authors, reviewers, and to the editorial staff of MDPI for their professionalism.

Conflicts of Interest: The authors declare no conflict of interest.

\section{References}

1. Fedoroff, N.V.; Battisti, D.S.; Beachy, R.N.; Cooper, P.J.; Fischhoff, D.A.; Hodges, C.N.; Knauf, V.C.; Lobell, D.; Mazur, B.J.; Molden, D.; et al. Radically rethinking agriculture for the 21st century. Science 2010, 327, 833-834. [CrossRef]

2. Fita, A.; Rodriguez-Burruezo, A.; Boscaiu, M.; Prohens, J.; Vicente, O. Breeding and domesticating crops adapted to drought and salinity: A new paradigm for increasing food production. Front. Plant Sci. 2015, 6, 978. [CrossRef] [PubMed]

3. Gull, A.; Lone, A.A.; Islam Wani, N.U. Biotic and abiotic stresses in plants. In Abiotic and Biotic Stress in Plants; de Oliveira, A.B., Ed.; IntechOpen: London, UK, 2019.

4. Zhu, J.K. Plant salt tolerance. Trends Plant Sci. 2001, 6, 66-71. [CrossRef]

5. Shah, T.M.; Imran, M.; Atta, B.M.; Ashraf, M.I.; Hameed, A.; Waqar, I.; Shafiq, M.; Hussain, K.; Naveed, M.; Aslam, M.; et al. Selection and screening of drought tolerant high yielding chickpea genotypes based on physio-biochemical indices and multi-environmental yield trials. BMC Plant Biol. 2020, 20, 171. [CrossRef]

6. Zhu, J.K. Abiotic stress signaling and responses in plants. Cell 2016, 167, 313-324. [CrossRef] 
7. Machado, R.M.A.; Serralheiro, R.P. Soil salinity: Effect on vegetable crop growth. Management practices to prevent and mitigate soil salinization. Horticulture 2017, 3, 30. [CrossRef]

8. Munns, R. Comparative physiology of salt and water stress. Plant Cell Environ. 2002, 25, 239-250. [CrossRef] [PubMed]

9. Munns, R.; Tester, M. Mechanisms of salinity tolerance. Annu. Rev. Plant Biol. 2008, 59, 651-681. [CrossRef]

10. Khan, A.; Pan, X.; Najeeb, U.; Yuen Tan, D.K.; Fahad, S.; Zahoor, R.; Luo, H. Coping with drought: Stress and adaptive mechanisms, and management through cultural and molecular alternatives in cotton as vital constituents for plant stress resilience and fitness. Biol. Res. 2018, 51, 47. [CrossRef]

11. Hernández, J.A. Salinity tolerance in plants: Trends and perspectives. Int. J. Mol. Sci. 2019, $20,2408$. [CrossRef]

12. Nemeskéri, E.; Helyes, L. Physiological responses of selected vegetable crop species to water stress. Agronomy 2019, 9, 447. [CrossRef]

13. Ketehouli, T.; Idrice Carther, K.F.; Noman, M.; Wang, F.-W.; Li, X.-W.; Li, H.-Y. Adaptation of plants to salt stress: Characterization of $\mathrm{Na}^{+}$and $\mathrm{K}^{+}$transporters and role of CBL gene family in regulating salt stress response. Agronomy 2019, 9, 687. [CrossRef]

14. Thangthong, N.; Jogloy, S.; Punjansing, T.; Kvien, C.K.; Kesmala, T.; Vorasoot, N. Changes in root anatomy of peanut (Arachis hypogaea L.) under different durations of early season drought. Agronomy 2019, 9, 215. [CrossRef]

15. Zeeshan, M.; Lu, M.; Sehar, S.; Holford, P.; Wu, F. Comparison of biochemical, anatomical, morphological, and physiological responses to salinity stress in wheat and barley genotypes deferring in salinity tolerance. Agronomy 2020, 10, 127. [CrossRef]

16. Brenes, M.; Solana, A.; Boscaiu, M.; Fita, A.; Vicente, O.; Calatayud, Á.; Prohens, J.; Plazas, M. Physiological and biochemical responses to salt stress in cultivated eggplant (Solanum melongena L.) and in S. insanum L., a close wild relative. Agronomy 2020, 10, 651. [CrossRef]

17. Fess, T.L.; Kotcon, J.B.; Benedito, V.A. Crop breeding for low input agriculture: A sustainable response to feed a growing world population. Sustainability 2011, 3, 1742-1772. [CrossRef]

18. Arteaga, S.; Yabor, L.; Díez, M.J.; Prohens, J.; Boscaiu, M.; Vicente, O. The use of proline in screening for tolerance to drought and salinity in common bean (Phaseolus vulgaris L.) genotypes. Agronomy 2020, 10, 817. [CrossRef]

19. Sumalan, R.M.; Ciulca, S.I.; Poiana, M.A.; Moigradean, D.; Radulov, I.; Negrea, M.; Crisan, M.E.; Copolovici, L.; Sumalan, R.L. The antioxidant profile evaluation of some tomato landraces with soil salinity tolerance correlated with high nutraceutical and functional value. Agronomy 2020, 10, 500. [CrossRef]

20. Kondwakwenda, A.; Sibiya, J.; Zengeni, R.; Musvosvi, C.; Tesfay, S. Screening of provitamin-A maize inbred lines for drought tolerance: Beta-carotene content and secondary traits. Agronomy 2019, 9, 692. [CrossRef]

21. Urano, K.; Kurihara, Y.; Seki, M.; Shinozaki, K. 'Omics' analyses of regulatory networks in plant abiotic stress responses. Curr. Opin. Plant Biol. 2010, 13, 132-138. [CrossRef]

22. Hou, Z.; Yin, J.; Lu, Y.; Song, J.; Wang, S.; Wei, S.; Liu, Z.; Zhang, Y.; Fang, Z. Transcriptomic analysis reveals the temporal and spatial changes in physiological process and gene expression in common buckwheat (Fagopyrum esculentum Moench) grown under drought Stress. Agronomy 2019, 9, 569. [CrossRef]

23. Jia, S.; Li, H.; Jiang, Y.; Tang, Y.; Zhao, G.; Zhang, Y.; Yang, S.; Qiu, H.; Wang, Y.; Guo, J.; et al. Transcriptomic analysis of female panicles reveals gene expression responses to drought stress in maize (Zea mays L.). Agronomy 2020, 10, 313. [CrossRef]

24. Liu, C.; Zhao, Y.; Zhao, X.; Wang, J.; Gu, M.; Yuan, Z. Transcriptomic profiling of pomegranate provides insights into salt tolerance. Agronomy 2020, 10, 44. [CrossRef]

25. Moradtalab, N.; Hajiboland, R.; Aliasgharzad, N.; Hartmann, T.E.; Neumann, G. Silicon and the association with an arbuscular-mycorrhizal fungus (Rhizophagus clarus) mitigate the adverse effects of drought stress on strawberry. Agronomy 2019, 9, 41. [CrossRef]

26. Minh, B.M.; Linh, N.T.; Hanh, H.H.; Hien, L.T.T.; Thang, N.X.; Hai, N.V.; Hue, H.T.T. A LEA gene from a Vietnamese maize landrace can enhance the drought tolerance of transgenic maize and tobacco. Agronomy 2019, 9, 62. [CrossRef] 
27. Abdelaal, K.A.; EL-Maghraby, L.M.; Elansary, H.; Hafez, Y.M.; Ibrahim, E.I.; El-Banna, M.; El-Esawi, M.; Elkelish, A. Treatment of sweet pepper with stress tolerance-inducing compounds alleviates salinity stress oxidative damage by mediating the physio-biochemical activities and antioxidant systems. Agronomy 2020, 10, 26. [CrossRef]

28. IPCC. Climate Change. 2014: Impacts, Adaptation, and Vulnerability. Part B: Regional Aspects. Contribution of Working Group II to the Fifth Assessment Report of the Intergovernmental Panel on Climate Change; Cambridge University Press: Cambridge, UK; New York, NY, USA, 2014.

29. Loreti, E.; van Veen, H.; Perata, P. Plant responses to flooding stress. Curr. Opin. Plant Biol. 2016, 33, 64-71. [CrossRef]

30. Bashar, K.K.; Tareq, M.Z.; Amin, M.R.; Honi, U.; Tahjib-Ul-Arif, M.; Sadat, M.A.; Hossen, Q.M.M. Phytohormone-mediated stomatal response, escape and quiescence strategies in plants under flooding stress. Agronomy 2019, 9, 43. [CrossRef]

31. Vwioko, E.D.; El-Esawi, M.A.; Imoni, M.E.; Al-Ghamdi, A.A.; Ali, H.M.; El-Sheekh, M.M.; Abdeldaym, E.A.; Al-Dosary, M.A. Sodium azide priming enhances waterlogging stress tolerance in okra (Abelmoschus esculentus L.). Agronomy 2019, 9, 679. [CrossRef]

32. Wassie, M.; Zhang, W.; Zhang, Q.; Ji, K.; Chen, L. Effect of heat stress on growth and physiological traits of alfalfa (Medicago sativa L.) and a comprehensive evaluation for heat tolerance. Agronomy 2019, 9, 597. [CrossRef]

33. Eremina, M.; Rozhon, W.; Poppenberger, B. Hormonal control of cold stress responses in plants. Cell. Mol. Life Sci. 2016, 73, 797-810. [CrossRef] [PubMed]

34. Li, Y.; Zhang, Q.; Ou, L.; Ji, D.; Liu, T.; Lan, R.; Li, X.; Jin, L. Response to the cold stress signaling of the tea plant (Camellia sinensis) elicited by chitosan oligosaccharide. Agronomy 2020, 10, 915. [CrossRef]

35. Anwar, A.; Wang, J.; Yu, X.; He, C.; Li, Y. Substrate application of 5-aminolevulinic acid enhanced low-temperature and weak-light stress tolerance in cucumber (Cucumis sativus L.). Agronomy 2020, 10, 472. [CrossRef]

36. Diffenbaugh, N.S.; Pal, J.S.; Giorgi, F.; Gao, X. Heat stress intensification in the Mediterranean climate change hotspot. Geophys. Res. Lett. 2007, 34, 11. [CrossRef]

37. Martínez-Nieto, M.I.; Estrelles, E.; Prieto-Mossi, J.; Roselló, J.; Soriano, P. Resilience capacity assessment of the traditional Lima Bean (Phaseolus lunatus L.) landraces facing climate change. Agronomy 2020, 10, 758. [CrossRef]

38. Nelimor, C.; Badu-Apraku, B.; Tetteh, A.Y.; Garcia-Oliveira, A.L.; N'guetta, A.P. Assessing the potential of extra-early maturing landraces for improving tolerance to drought, heat, and both combined stresses in maize. Agronomy 2020, 10, 318. [CrossRef]

39. Probert, M.E.; Keating, B.A. What soil constraints should be included in crop and forest models? Agric. Ecosyst. Environ. 2000, 82, 273-281. [CrossRef]

40. Kauranne, L.-M.; Kemppainen, M. Urgent need for action in the Baltic sea area. In Phosphorus in Agriculture: 100\% Zero; Springer: Dordrecht, The Netherlands, 2016; pp. 1-6.

41. Pereira-Dias, L.; Gil-Villar, D.; Castell-Zeising, V.; Quiñones, A.; Calatayud, A.; Rodríguez-Burruezo, A.; Fita, A. Main root adaptations in pepper germplasm (Capsicum spp.) to phosphorus low-input conditions. Agronomy 2020, 10, 637. [CrossRef]

42. Hefferon, K. Biotechnological approaches for generating zinc-enriched crops to combat malnutrition. Nutrients 2019, 11, 253. [CrossRef]

43. Szopiski, M.; Sitko, K.; Gierón, Z.; Rusinowski, S.; Corso, M.; Hermans, C.; Verbruggen, N.; Małkowski, E. Toxic effects of $\mathrm{Cd}$ and $\mathrm{Zn}$ on the photosynthetic apparatus of the Arabidopsis halleri and Arabidopsis arenosa Pseudo-Metallophytes. Front. Plant Sci. 2019, 10, 748. [CrossRef]

44. Fatemi, H.; Zaghdoud, C.; Norteempes, P.A.; Carvajal, M.; Martínez-Ballesta, M.C. Differential aquaporin response to distinct effects of two $\mathrm{Zn}$ concentrations after foliar application in pak choi (Brassica rapa L.) plants. Agronomy 2020, 10, 450. [CrossRef]

45. Leghari, S.J.; Wahocho, N.A.; Laghari, G.M.; Talpur, K.H.; Wahocho, S.A.; Lashari, A.A. Role of nitrogen for plant growth and development: A review. Adv. Environ. Biol. 2016, 10, 209-2018.

46. Kong, L.; Xie, Y.; Hu, L.; Si, J.; Wang, Z. Excessive nitrogen application dampens antioxidant capacity and grain filling in wheat as revealed by metabolic and physiological analyses. Sci. Rep. 2017, 7, 43363. [CrossRef] [PubMed] 
47. Gil-Ortiz, R.; Naranjo, M.Á.; Ruiz-Navarro, A.; Caballero-Molada, M.; Atares, S.; García, C.; Vicente, O. New eco-friendly polymeric-coated urea fertilizers enhanced crop yield in wheat. Agronomy 2020, 10, 438. [CrossRef]

48. Muñoz, M.; Torres-Pagán, N.; Peiró, R.; Guijarro, R.; Sánchez-Moreiras, A.M.; Verdeguer, M. Phytotoxic effects of three natural compounds: Pelargonic acid, carvacrol, and cinnamic aldehyde, against problematic weeds in Mediterranean crops. Agronomy 2020, 10, 791. [CrossRef]

49. Mayoral, O.; Solbes, J.; Cantó, J.; Pina, T. What has been thought and taught on the lunar influence on plants in agriculture? Perspective from physics and biology. Agronomy 2020, 10, 955. [CrossRef] 